\title{
Heterogeneous country responses to the Great Recession: the role of supply chains
}

\author{
Steven Brakman ${ }^{1}$. Charles van Marrewijk ${ }^{2}$
}

Published online: 27 March 2019

(c) The Author(s) 2019

\begin{abstract}
The one time shock of the Great Recession in 2008/9 opens up the opportunity to study the sensitivity of countries to global economic shocks. Some countries are more resilient to global shocks than others. The authors analyze the link between the country response to the Great Recession and participation in global supply chains. Their preferred measure of supply chains is the Grubel-Lloyd index, which enables us to use detailed trade data over longer periods of time. The main finding is that strong involvement in global supply chains slows down the recovery of countries to recessions. Europe, which is heavily involved in global supply chains, is a case in point.
\end{abstract}

Keywords Great Recession · Supply chains · Heterogeneous country responses

JEL Classification E32 $\cdot$ F14 $\cdot$ F44

\section{Introduction}

Shocks affect countries differently. Some countries are hit particularly hard by a shock, and others are not. For natural disasters this is hardly surprising, as these are often country-specific, but why macro-economic, or economy wide shocks affect countries differently is the topic of a growing body of literature. ${ }^{1}$

\footnotetext{
1 See for examples and recent surveys: (i) the 2010 special issue of the Cambridge Journal of Regions, Economy, and Society on The Resilient Region, (ii) the 2014 special issue of Raumforschung und Raumordnung on Regional Economic Resilience: Policy Experiences and Issues in Europe, and (iii) the 2016 special issue of Regional Studies on Resilience Revisited.
}

Steven Brakman

s.brakman@rug.nl

Charles van Marrewijk

J.G.M.vanMarrewijk@uu.nl

1 University of Groningen, PO Box 800, 9700 AV Groningen, The Netherlands

2 Utrecht University, Utrecht, The Netherlands 


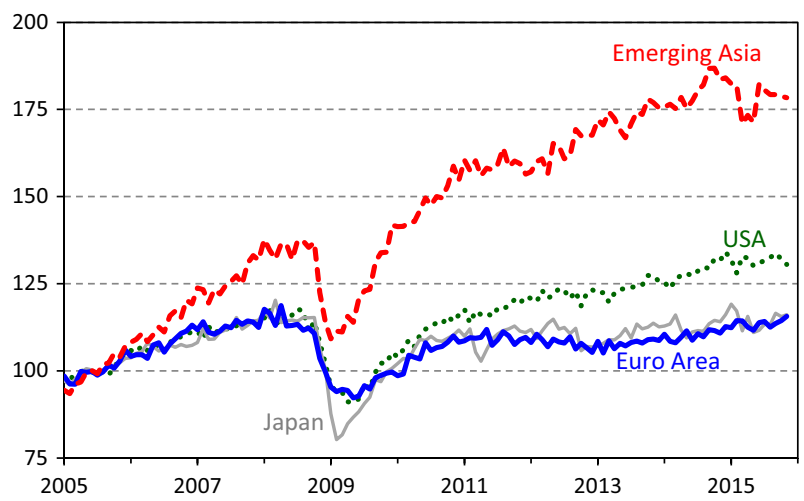

Fig. 1 Volume of trade, selected global regions and countries; index $(2005=100)$. Source: Based on monthly data from CPB Netherlands Bureau for Economic Policy Analysis (CPB); trade volume for a country or region is average of export and import index

The Great Recession, which started in 2008, is an example of an economywide shock which illustrates that not all countries respond in the same way. Figure 1 illustrates this for Asia, the USA and the Euro area. The size of this shock has not been seen since the 1930s, see Irwin (2012). We analyse the role played by international trade linkages through supply chains (or global value chains) in the decline and recovery process following the Great Recession using various measures related to value-added trade flows (forward, backward, and total linkages) and the Grubel-Lloyd index of intra-industry trade.

The Grubel-Lloyd index has the advantage that it allows us to use more detailed data than value-added measures. In general, we find hardly any effect for the valueadded measures of supply chains, but strong effects for the Grubel-Lloyd index: a more intense involvement in intra-industry trade flows implies that the duration of the trade recovery takes longer, such that the timing of the recovery is later. This finding also helps us to, partially, explain Europe's recovery problem, see Salvatore (2017).

The observation that countries respond differently to shocks is by now wellestablished, see Fingleton et al. (2012), Brakman et al. (2015b), Martin and Sunley (2015), Bailey and Turok (2016), and Martin et al. (2016). These studies, however, have an inward-looking methodology; countries are most often studied in isolation with scant attention for linkages between countries and the global economy. This is remarkable as the recent attention for supply chains hints at a relationship between the different responses of countries to shocks and international linkages. The World Trade Organization (2009, p. 2), for example, notes: “...the magnitude of recent declines relates to the increasing presence of global supply chains in total trade...-goods cross many frontiers during the production process and components in the final product are counted every time they cross a frontier. ... this effect, whose magnitude can only be guessed at in the absence of systematic information..." Altomonte et al. (2012) observe that along a global supply chain shocks as well 
as recoveries can be magnified due to 'inventory' effects (the so-called bullwhip effect). ${ }^{2}$ Brakman et al. (2015b) suggest a link between regional specialization patterns (due to comparative advantage) and resilience. ${ }^{3}$ If specialization patterns are driven by international competition then a link between trade and resilience should be visible.

At the country level, the current discussion on the impact of supply chains on the Great Recession is inconclusive, ranging from Altomonte et al. (2012) on the one hand to Wagner and Gelübcke (2014) and Behrens et al. (2013) on the other hand. In these studies, Altomonte et al. (2012) note for France that along a global supply chain shocks as well as recoveries can be magnified due to a bullwhip effect, Wagner and Gelübcke (2014) conclude for Germany that the hypothesis that foreign multinationals are more volatile following a negative shock is not supported by their empirical research, while Behrens et al. (2013) conclude that value chains play a minor role in Belgium, and in line with this observation Bems et al. (2011) find a dampening effect of supply chains on the trade collapse of 2009.

For this paper it is, however, not the inconclusiveness of the debate that is interesting: it is whether the heterogeneity of country experiences can be linked to participation in global supply chain linkages. Our main conclusion is straightforward; a strong involvement in global supply chains as measured by the Grubel-Lloyd index slows down the recovery of countries to recessions. Our findings are consistent with Altomonte et al. (2012) who point out that with longer supply chains a bullwhip effect is likely and that the impact of (export) credit restraints after the crisis might have restricted trade along supply chains.

Section 2 describe the data and provides some highlights on the Great Recession and the timing of various stages of the 'trade-cycle'. Section 3 explains our methodology. Section 4 discusses some advantages and disadvantages of measures of supply chains. Section 5 links these measures to the Great Recession, while Sect. 6 provides a survival analysis. Section 7 concludes.

\section{Data and descriptive statistics}

We use four main data sources. First, our primary data source for the analysis below on the timing and extent of the Great Recession is based on real monthly data (based on gross trade flows) from the World Trade Monitor (WTM) kindly provided to us by the Netherlands Bureau for Economic Policy Analysis (CPB). ${ }^{4}$ The objective of the WTM is to provide a monitor for developments in global international trade as well as industrial production, but we restrict attention to trade flows only. The CPB processes over 3300 source series for its trade data on the basis of which it compiles

\footnotetext{
${ }^{2}$ The bullwhip effect indicates that changes along the supply chain become magnified as they built on one each other. At the end of the chain the effects are large. Altomonte et al. (2012) focus on the ownership structure of French firms and find that the magnifying effects of supply chains is larger for within firm trade than for arms's length trade.

3 See Brakman and van Marrewijk (2017) and Ceglowski (2017) on measuring comparative advantages and Egger et al. (2017) on connections associated with goods-trade networks.

4 We refer to this data as CPB-WTM data.
} 
generic monthly series for each included country that is standardized regarding frequency (monthly), denomination (US dollar), indexation, and seasonal and working day adjustment. In addition, the CPB compiles a consistent series of values, prices, and volumes, see CPB (2013) for technical details. We focus attention on monthly trade volume data measured in millions of constant 2005 US dollar for 80 individual countries.

Figure 1 already shows a big difference in trade recovery (resilience) for global regions. The $\mathrm{CPB}$ identifies eight major regions (four advanced regions and four emerging regions). At the aggregate level, the timing of the trough (the minimum) occurs early in Emerging Asia and at about the same time in other countries. The timing of the recovery, that is the return to the pre-crisis trade volume, varies enormously. It is quick in Emerging Asia and slow in the Euro Area. The paper analyzes countries (and not global regions), as illustrated by the slow recovery in Japan and the intermediate recovery in the USA in Fig. 1.

To analyse the possible connections between supply chains and the Great Recession we use three main secondary data sources, namely the (i) World Development Indicators (WDI) online, (ii) the OECD-WTO Trade in Value Added (TiVA) database, and (iii) the Brülhart (2008) intra-industry trade data.

(i) The WDI is our source of information on population (in million) and income per capita (GDP PPP in constant 2011 international dollars). The income data is supplemented with information from the CIA World Factbook for missing data, see van Marrewijk (2017) for details.

(ii) The TiVA database is our source of information for value-added based indicators of supply chain involvement, such as backward linkages (the share of foreign value-added in gross exports) and forward linkages (the share of domestic value-added directed to intermediate goods in gross exports).

(iii) We use the Brülhart data, compiled in preparation for the World Bank (2009) World Development Report, as our source for a country's involvement in intraindustry trade flows. Note that Brülharts results are based on detailed gross trade flows, where we use his 5-digit and 3-digit trade-weighted Grubel-Lloyd index as an indicator for supply chain involvement. Whenever we refer to the Grubel-Lloyd index, please keep in mind that it is based on gross trade flows.

Based on the CPB-WTM real gross trade data, the pre-crisis peak in world trade occurs in March 2008, the crisis-trough occurs 12 months later in March 2009, and it takes another 20 months until November 2010 for trade to recover to the pre-crisis peak level. This timing varies, of course, for the 76 individual countries we analyse.

- The median country peak occurs in April 2008, ranging from January 2007 for Ireland and Italy to January 2009 for Paraguay.

- The median country trough occurs in April 2009 (1 year after the peak), ranging from the first trough in November 2008 for Vietnam to the last trough 1 year and 11 months later in October 2010 for Oman.

- As of the start of 2016 (using information up to February) no less than 16 countries $(21 \%$ of all countries, representing $27 \%$ of the trade flows) still had not 
(a) cumulative; percent of total trade

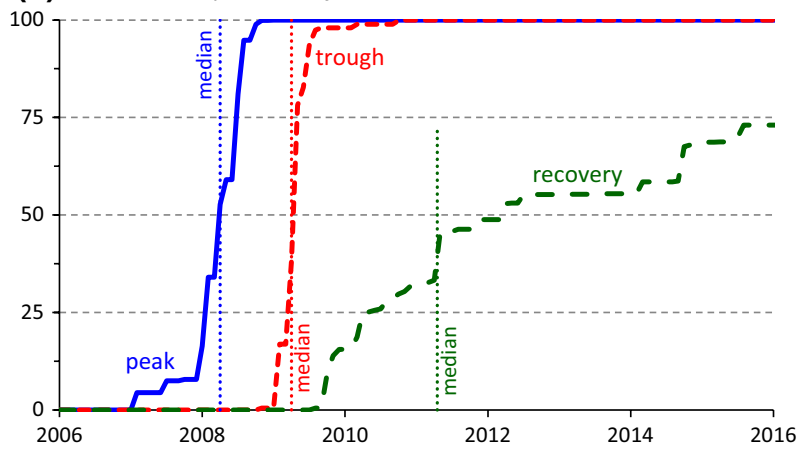

(b) cumulative; number of countries

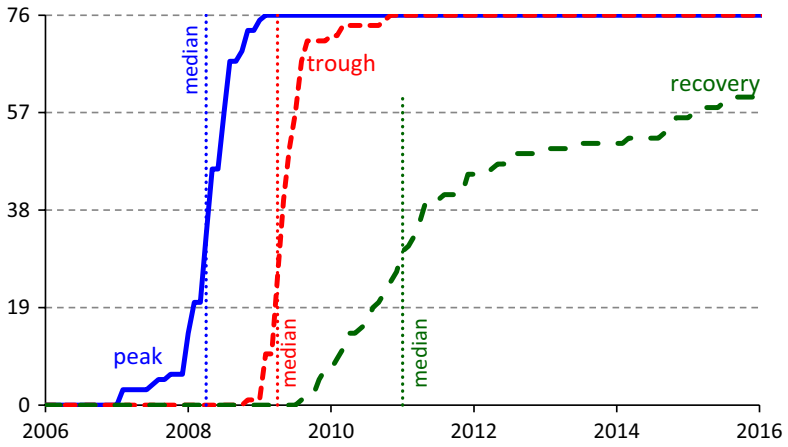

Fig. 2 Timing of peak, trough, and recovery; cumulative distribution. Source: Authors's calculations using centered 5-month moving average trade (see Sect. 3); the median values for recovery are based on the countries who have recovered in 2016

recovered their trade flows to the pre-crisis peak level. Of the 60 countries that did recover, the median recovery occurred in January 2011, ranging from the first recovery in August 2009 for Vietnam to the most recent recovery 6 years later in August 2015 for Belgium.

These observations are illustrated using cumulative distributions in Fig. 2 in two panels, where panel $a$ uses the country's weight in total trade flows and panel $b$ uses the country as unit of observation. The figure illustrates that the timing of the trough is quite steep around April 2009 and that the time to recovery varies substantially between countries. In fact, 16 countries had not yet recovered; namely three countries in Asia (Iran, Japan, and United Arab Emirates) and 13 countries in Europe (Austria, Croatia, Cyprus, Denmark, Finland, France, Italy, Norway, Portugal, Spain, Sweden, Ukraine, and UK).

Table 1 provides basic statistics on the Great Recession at the country level. We already discussed the median, minimum, and maximum values for the timing of peak, trough, and recovery. The average timing is close to the median value for 
Table 1 Summary of Great Recession statistics, country level. Source: Authors's calculations

\begin{tabular}{|c|c|c|c|c|c|c|}
\hline & Average & Median & Minimum & Maximum & SD & \#Obs \\
\hline Peak & 2008.25 & 2008.25 & 2007.00 & 2009.00 & 0.39 & 76 \\
\hline Trough & 2009.35 & 2009.25 & 2008.83 & 2010.75 & 0.31 & 76 \\
\hline Recovery & 2011.58 & 2011.04 & 2009.58 & 2015.58 & 1.65 & 60 \\
\hline Size (\%) & 20.93 & 20.60 & 3.76 & 45.45 & 6.92 & 76 \\
\hline \multicolumn{7}{|c|}{ Duration (months) } \\
\hline Decline & 13.2 & 12 & 6 & 37 & 5.53 & 76 \\
\hline Recovery & 27.1 & 21 & 6 & 76 & 19.46 & 60 \\
\hline Total & 39.7 & 35 & 13 & 97 & 22.01 & 60 \\
\hline \multicolumn{7}{|c|}{ Speed (\% per month) } \\
\hline Decline & 1.79 & 1.77 & 0.37 & 5.68 & 0.83 & 76 \\
\hline Recovery & 1.06 & 0.98 & 0.23 & 2.50 & 0.60 & 60 \\
\hline
\end{tabular}

Timing: $x .00=$ January, each extra month adds $1 / 12$; size $=$ extent of the decline from peak to trough in percent

peak and trough, but substantially higher for recovery, namely around August 2011 instead of February-March, indicating a skewed distribution. The standard deviation of the timing of the trough is 0.31 years, somewhat smaller than for the peak (0.39 years) and substantially smaller than for recovery (1.65 years). This indicates again large variation between countries in terms of recovery (see Table 7 in the "Appendix" for a complete list of countries).

The average size of the decline is $21 \%$, ranging from $3.8 \%$ for Bolivia to $45.4 \%$ for Ukraine. The median duration of the decline is 12 months, ranging from 6 months for six different countries to 37 months for Ireland. The median duration of the recovery (for the countries that have recovered) is 21 months, ranging from 6 months for Indonesia to 76 months for Belgium and Malaysia. The median total duration (decline plus recovery for the countries that have recovered) is 35 months, ranging from 13 months for Paraguay (14 months for China and South Korea) to 97 months for Ireland. In all cases the average duration is higher than the median.

The median speed of the decline is $1.8 \%$ per month, substantially faster than the median speed of recovery which is $1.0 \%$ per month. The speed of the decline ranges from about $0.4 \%$ per month for Algeria, Oman, and Ireland to 5.7\% per month for Ukraine. The speed of recovery ranges from a crawling $0.23 \%$ per month for Belgium to more than ten times that speed for China and Paraguay. The variation between countries is large.

Our hypothesis is that international trade linkages could explain the differences between countries with respect to the way they experienced the great recession. A straightforward measure of linkages is to look at global supply chains. Modern trade is characterized by the fragmentation of the production process that links countries to each other (Baldwin 2016). This linkage implies that a shock on one end of this chain could travel all the way to the other end. 


\section{Methodology}

We apply a simple definition of recovery; the time it takes to recover from a shock, that is, to return to the original (trend) level. We do not look at possible changes in sector structure or innovations that could be important for recovery. Our methodology is most easily explained by example. Figure 3 depicts the volume of 'trade' flows, which is calculated as the average of exports and imports. At the world level the difference between exports and imports is less than $0.3 \%$ in January 2008 (which is the index month in Fig. 3, see below). For individual countries this difference can, of course, be much larger as countries can have a substantial trade surplus or deficit at a point in time.

The solid line in Fig. 3 depicts the monthly volume of world trade, which varies substantially from 1 month to the next. The Great Recession adversely affected the volume of world trade in particular from July 2008 to March 2009, while recovery is clear in the second half of 2009. To investigate the extent of the recession, the duration of the decline, and the speed at which the recession affected the volume of trade, we have to determine the pre-recession 'peak' as well as the 'trough', the low point of the recession. To investigate the duration of the recovery from the recession and the speed at which this occurs, we have to determine the post-recession 'recovery'.

1. We define the peak as the maximum volume of trade in the period January 2007March 2009. ${ }^{5}$ Using monthly data at the world level the peak occurs in January 2008 , which we therefore take as the basis for our volume index.

2. We define the trough as the minimum volume of trade in the period 2008-2010. Using monthly data at the world level the trough occurs in May 2009, with an index of 79.5. This implies that the extent of the decline (the fall since the peak) for the world is $20.5 \%$, the duration of the decline (from peak to trough) is 16 months, and the average speed of the decline is $1.28 \%$ per month $(=20.5 / 16$ $\%)$.

3. We define recovery as the first post-trough moment the volume of trade exceeds the peak level. Using monthly data at the world level recovery occurs in November 2010. This implies that the duration of the recovery (from trough to recovery) for the world is 18 months, the speed of the recovery is $1.14 \%$ per month $(=20.5 / 18 \%)$, and the total duration (from peak to recovery) is 34 months (16 plus 18).

It is apparent from Fig. 3 that determining peak, trough, and recovery on the basis of monthly data depends to a fair extent on the 'natural' monthly fluctuations, even at the world level. After the peak in January 2008, for example, the volume of world trade declines in February and March of 2008, but then bounces back to almost the January level (at 99.8\%) in April 2008, which could therefore be taken as an 'almost

\footnotetext{
5 This is 1 year before the global peak in levels to 1 year after the global peak in 5-month moving average, see below for details.
} 


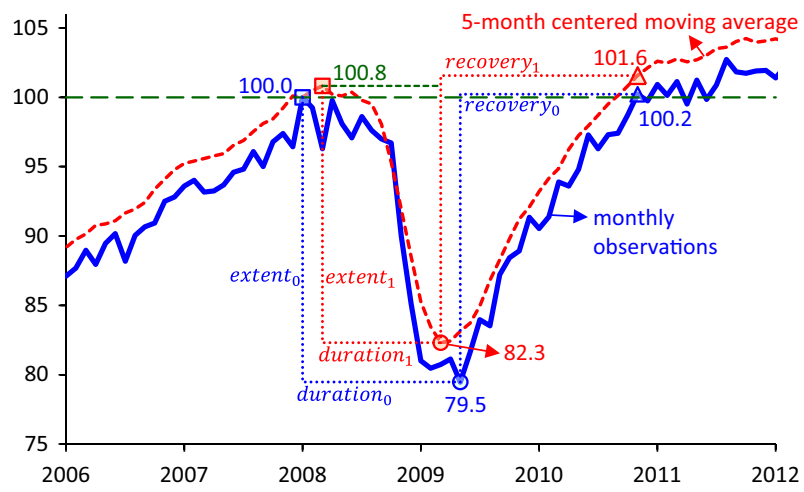

Fig. 3 The Great Recession; volume of world trade, index (January 2008=100). Source: Compiled from CPB-WTM gross trade volume; trade is average of export and import volume; square is peak; circle is trough; triangle is recovery

peak'. Similarly, after the recovery in November 2010 the volume of trade declines below the peak level in December 2010 (at 99.7\%) before bouncing back above that level in January 2011.

To reduce the impact of monthly fluctuations we calculated 5-month centered moving average trade flows, which are also depicted in Fig. 3. Using the methodology outlined above for this new series, the peak of world trade occurs 2 months later in March 2008 (at an index of 100.8), the trough occurs 2 months earlier in March 2012 (at an index of 82.3), and recovery occurs in the same month (November 2010). The timing of peak, trough, and recovery based on the centered 5-month moving average series is quite clear; note that the extent of the decline is somewhat smaller $(=100 *(100.8-82.3) / 100.8=18.4$ instead of $20.5 \%)$, the duration of the decline is somewhat shorter (12 instead of 16 months), the speed of the decline is somewhat higher $(=18.4 / 12=1.53$ instead of $1.28 \%$ per month $)$, the duration of the recovery is somewhat longer (20 instead of 18 months), the speed of the recovery is somewhat smaller $(=18.4 / 20=0.92$ instead of $1.14 \%$ per month $)$, and the total duration is somewhat shorter (32 instead of 34 months). Also note that all measures are related to the peak at 100.8 (and not the index value 100).

Our analysis is based at the volume of trade flows at the country level using the centered 5-month moving average methodology (from now on: unless stated otherwise). We have data for 80 individual countries (see for a complete list Table 7 in the "Appendix"). The idea is to have a country information similar to that depicted in Fig. 3, such that we can attribute timing, decline, and recovery to the Great Recession and not to other fluctuations or influences. For two countries (Iraq and Qatar) trade flows continued to rise for at least five more months beyond the peak of point 1 above. For two countries (Greece and Luxembourg) trade flows continued to decline to a minimum below the trough of point 2 above. These four countries were excluded from the analysis; see Table 1 for an overview of the 76 included countries 
(accounting for 5.4 billion people [3/4th of the world population] and more than $90 \%$ of world trade flows). ${ }^{6}$

\section{Measuring supply chains}

Adequately measuring supply chains is notoriously difficult as it involves the simultaneous importing and exporting of goods and components at different stages of the production process in related sectors. Streams are usually co-ordinated at the firm level, often involving multinational enterprises and different countries (allowing for differences in comparative advantages). As a consequence, supply chains connect countries at different levels of economic development.

One way to measure supply chains is to focus on the value-added at different stages of the production process. Great advances have been made recently, for example thanks to the work of the World Input Output Data (WIOD) database at the University of Groningen (www.wiod.orgy) and the combined work of the Organization of Economic Cooperation and Development (OECD) and the World Trade Organization (WTO) in the Trade in Value Added (TiVA) database. We use the TiVA database as it incorporates a larger range of countries. At the country level, supply chains are measured in the TiVA database in three different ways:

- Backward linkages; this measures the share of value-added in export flows that is imported from abroad.

- Forward linkages; this measures the share of domestic value-added content in export flows that is used as an intermediate input of foreign sectors.

- Total linkages; this is the sum of backward and forward linkages.

Figure 4 ranks countries according to Forward and Backward linkages (panel a), and Total linkages (panel b). As Fig. 4a illustrates, the countries with the highest scoring forward linkages are the oil exporting nations Saudi Arabia and Brunei $(87 \%$ of gross exports). This reflects the fact that most of the exported oil is used as an intermediate input in virtually all sectors of the importing countries. Other countries with high forward linkages are Russia and Rest of World (70\% of gross exports). The global average forward linkage is $49 \%$ of gross exports, which is about equal to the value for the UK and close to the values for USA (51\%) and Germany (46\%).

The highest backward linkage by far is provided by Luxembourg (59\%). This reflects the fact that many sectors in Luxembourg intensively use imported intermediate inputs in the production process. The backward linkages are equal to one minus the domestic value-added share. This implies that the countries scoring high in domestic value-added, such as Saudi Arabia, Brunei, Rest of World, and Russia, score low in backward linkages. The global average backward linkage is $24 \%$, which is close to the value for the UK, India, and Canada (the latter two are not identified

\footnotetext{
${ }^{6}$ Per cent of world trade is based on World Development Indicators online, sum of exports and imports of goods and services of included countries in 2008 (BoP, current USD); excludes Taiwan.
} 
(a) Backward and Forward Linkages

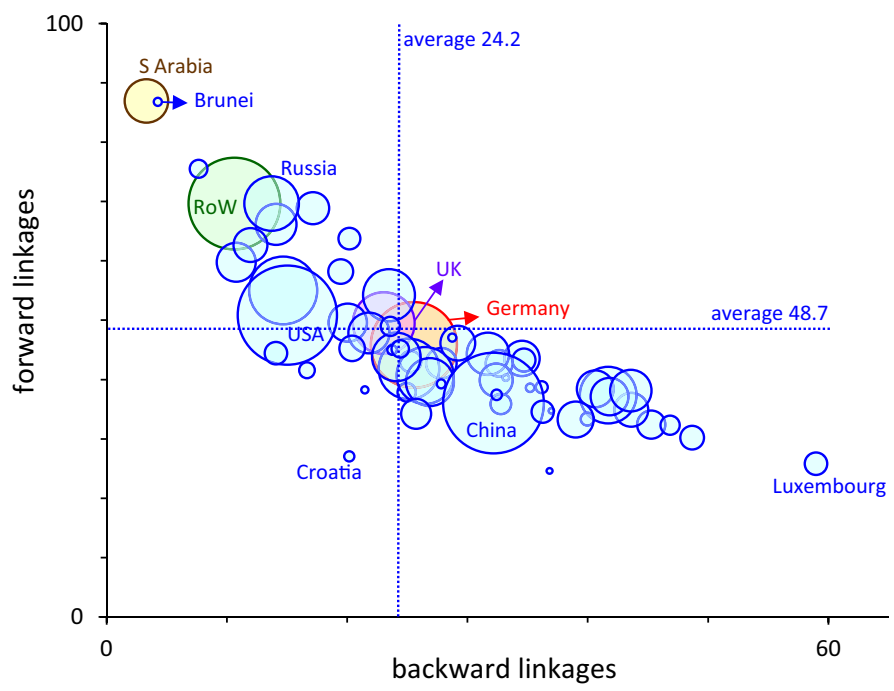

(b) Total Linkages: Sum of Backward and Forward Linkages

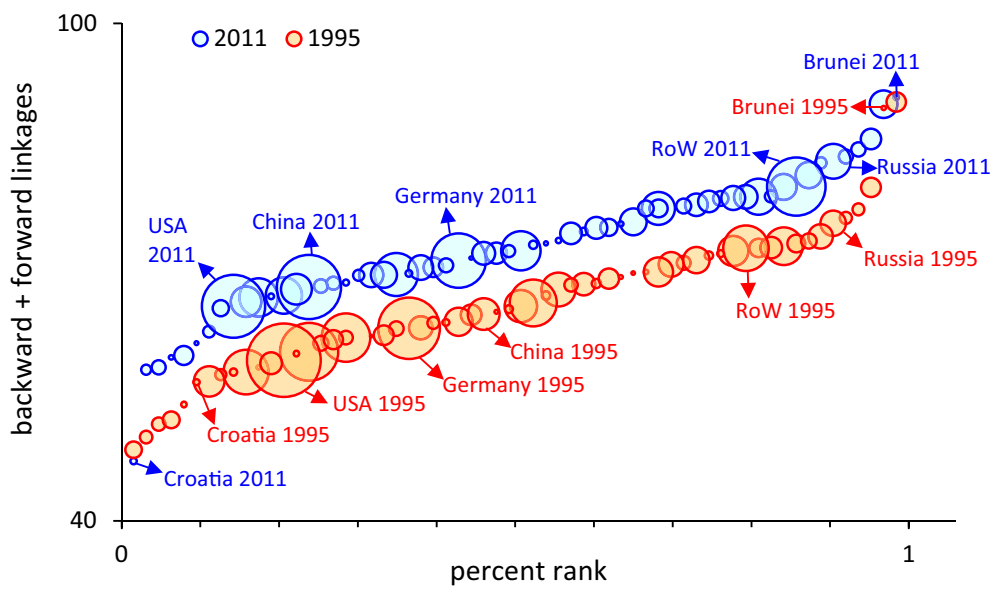

Fig. 4 Value-added based supply chain linkages. a Backward and forward linkages. b Total linkages: sum of backward and forward linkages. Source: Based on TiVA trade in value added database; bubble size proportional to gross exports

separately in the figure). The USA has clearly lower backward linkages (15\%), while Germany and China have higher backward linkages (26 and 32\%, respectively), reflecting the fact that German and Chinese sectors more intensively use imported components from other countries in their production processes than UK and USA.

The sum of the backward and forward linkages is generally taken as an indication of the intensity with which a country participates in global value chains, 
see Koopman et al. (2010). Figure 4b shows this measure for 1995 and 2011. It shows that participation in global value chains is rising over time: the values for the 2011 score tend to be above those for the 1995 score. The global average sum of backward and forward linkages increased from 65\% in 1995 to $73 \%$ in 2011 . The ranking tends to be rather persistent over time, with Germany and Rest of World moving up, while USA and China are moving down. Also note the increase in bubble size for China and Rest of World, indicating their rapidly rising importance in global trade flows.

Brakman et al. (2015a) discuss some advantages and disadvantages of measuring supply chains using value-added data. The main limitations are:

(i) The informational requirements for constructing the data are high. As a consequence, only a relatively small number of mostly advanced countries are included in the analysis. This makes it difficult to adequately assess the performance of the included countries relative to the excluded countries. It also means that countries with a lower level of economic development are excluded from the analysis. Indeed, none of the least developed countries is included in the WIOD database.

(ii) The number of sectors is limited. This is necessary since the construction uses input-output tables that are only available on a rather coarse scale. This contrasts with the detailed information involving thousands of goods for gross exports at the 5-digit level. Actual supply chains are based on this much more minute detail. As a consequence, the value added to gross export ratio has a problem adequately identifying the large countries involved in global supply chains (34 for TiVA and 35 for WIOD).

(iii) The value-added based measures can be deceptive. Let's take Saudi Arabia as an example (see Fig. 4). It's oil exports are used as an intermediate input in many countries. This does not mean that Saudi Arabia is part of supply chains in the sense that oil is part of fragmentation of the production processes that has been made possible by the information technology revolution (Baldwin 2016). Oil supplied by Saudi Arabia can easily be replaced by oil supply from another source (for example by shale oil produced in the US). In contrast, a faulty taptic engine for the Apple watch in 2015 disrupted the production process severely as no substitutes were available. Other examples are Brunei and Russia that also score high in the value-added index but their involvement in global supply chains mimics that of Saudi Arabia and is rather limited. As Fig. 4 illustrates the linkages for these countries are restricted to mostly forward linkages. On the other end of the picture, the USA, China, and Germany only score relatively low on the value-added supply chain index, whereas it is extensively documented that all three countries play an important role in many global supply chains (Baldwin 2016, p. 97). Their low score seems related to the relative size of their trade flows rather than their actual involvement in global supply.

Given these limitations an alternative measure of supply chains is warranted. A key characteristic of supply chains is the two-way nature of trade flows; a supply chain 
connects forward and backward linkages in international trade flows. This points towards the Grubel-Lloyd index as a possible alternative. The advantages of this measure are that (i) information is available for almost all countries, (ii) information is available at a detailed sector level, and (iii) it solves the 'too distant' valueadded problem of Saudi Arabia discussed above by excluding trade flows with other sectors. This, however, potentially introduces a bias. Since supply chains measured by the Grubel-Lloyd index involve two-way trade within the same sector, it can be biased if intermediate products come from outside the sector itself. Broadening the definition of sectors deals with this problem to some extent. This is what we do in our analysis where we use the Grubel-Lloyd index for 3-digit sectors and 5-digit sectors. The differences in the outcomes for these two different levels of aggregation are indicative for the size of the potential bias.

International supply chains involve the trade of intermediate goods from one location to another. This can be in the same sector (which is picked-up by the Grubel-Lloyd index), or from one sector to another (which is not included in the Grubel-Lloyd index, depending on the level of aggregation). Trade of final goods is not part of supply chains, but may be included in the Grubel-Lloyd index to the extent it is in the same sector. Under the technical assumption that most intermediate trade-within a supply chain - is trade within the same sector (in our case defined as a 3-digit or 5-digit sector) and that final product deliveries within the sectors do not systematically affect intra-industry trade flows, we can use the Grubel-Lloyd index as a method for measuring supply chains. The higher the index the more important are supply chains, see the "Appendix" for a brief sector discussion. We analyse these data based on the work of Brülhart (2008).

Note that a similar technical caveat holds for value-added measures which conceptually are more strictly related to supply chains than GL-index measures (that include trade in final products). In practice one has to deal with issues like data availability and strong assumptions. In a survey of global supply chain measures Johnson (2018) mentions-among other complications-that the construction of input-output data relies on imputation because of lacking data and tables are often only available at aggregated levels for benchmark years that are asynchronous across countries. Also sector classifications across countries differ and input-output tables are not always consistent with national account data. With respect to strong assumptions that have to be made, Johnson (2018) points towards the problematic assumptions that imported intermediate goods are used with the same input-output coefficients (intensity) in domestic production and exports at high levels of aggregation.

In this paper, we stress the use of the Grubel-Lloyd index as our preferred measure of supply chains, as it is more closely related to actual supply chains and allows us to use more detailed data than value-added based measures. For comparison and completeness, however, we also provide information on the links between valueadded based measures and the Great Recession in the discussion below. Our analysis of the Great Recession uses data for 76 countries. The TiVA database (covering 61 countries) provides information on the backward and forward linkages for 55 of our 76 countries. The Grubel-Lloyd index is available for all countries. Europe and 


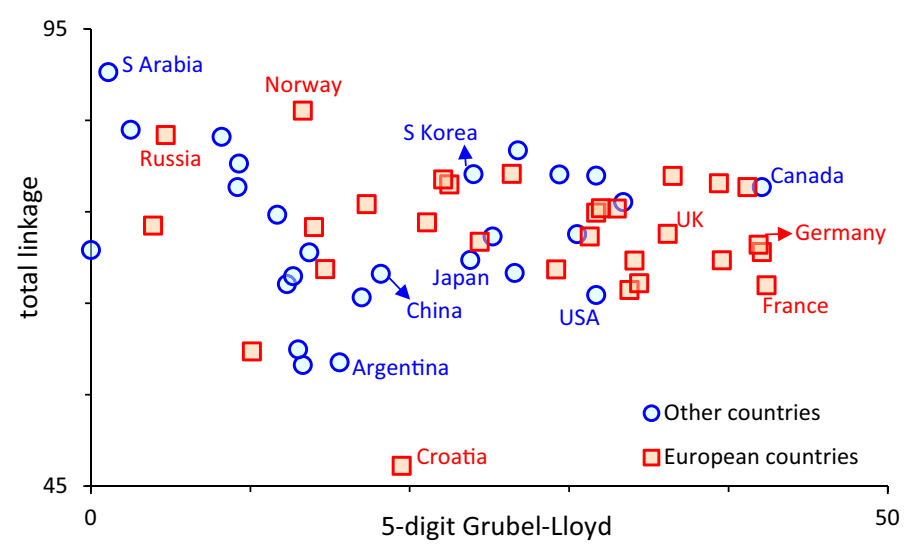

Fig. 5 Supply chain measures; total linkage and 5-digit Grubel-Lloyd. Source: Authors's calculations; 55 countries included

Table 2 Correlation coefficients between different supply chain measures. Source: Authors's calculations; 55 countries included

\begin{tabular}{lrrrr}
\hline & GL5 & \multicolumn{1}{l}{ GL3 } & Backward & Forward \\
\hline GL3 & 0.960 & 1.000 & & \\
Backward & 0.392 & 0.361 & 1.000 & \\
Forward & -0.386 & -0.356 & -0.782 & 1.000 \\
Total & -0.065 & -0.061 & 0.155 & 0.495 \\
\hline
\end{tabular}

Backward- and forward linkages are based on value-added trade flows, while Grubel-Lloyd index is based on gross trade flows

GL5 5-digit Grubel-Lloyd index, GL3 3-digit Grubel-Lloyd index

(especially) Germany are spiders in the supply chain web. ${ }^{7}$ Figure 5 therefore distinguishes between European and Other countries and provides information regarding the extent to which the total linkages supply chain measure is related to the 5-digit Grubel-Lloyd index: there is virtually no relationship between these two measures (the correlation coefficient is even mildly negative: -0.065 ).

Countries like Saudi Arabia and Russia score high on total linkages (thanks to their strong forward linkages) but low on the Grubel-Lloyd index; countries like Argentina and Croatia score low on total linkages and low-medium on Grubel-Lloyd index; countries like the UK and Germany score medium on total linkages and high on Grubel-Lloyd index. Other countries, such as Canada and the US also score high on the Grubel-Lloyd index.

Table 2 explains why the correlation between total linkages and the Grubel-Lloyd index is so low: there is a reasonably strong positive correlation between backward linkages and the Grubel-Lloyd index (0.392), which is almost perfectly compensated by a reasonably strong negative correlation between forward linkages and the

\footnotetext{
${ }^{7}$ The term spider indicates that supply chains are not necessarily linear, but that the 'spider 'receives intermediate inputs from all directions.
} 
Grubel-Lloyd index $(-0.386)$. The table also shows that there is a strong negative correlation between backward and forward linkages $(-0.782)$ : countries with high backward linkages tend to have low forward linkages, and vice versa. The next section thus analyzes backward and forward linkages both jointly and separately. As we explained above the Grubel-Lloyd (GL) index as a measure for supply chains can be sensitive to aggregation, we therefore provide estimates for both GL5 and GL3 measures separately in the regressions below for sensitivity reasons.

\section{Supply chains and the Great Recession}

We analyse the links between supply chains and the impact of the Great Recession. In Sect. 5.1 we focus on the Grubel-Lloyd index (based on gross exports). In Sect. 5.2 we provide an analysis using value-added measures.

\subsection{Grubel-Lloyd index and the Great Recession}

Section 4 suggests that some countries are more heavily involved in global supply chains. If supply chains have an important role to play in resilience these countries should stand-out in our analyses. Table 3 provides an overview of the differences

Table 3 Europe versus other country differences in supply chain characteristics. Source: Authors's calculations

\begin{tabular}{|c|c|c|c|c|c|}
\hline & GL5 & $\mathrm{GL5}^{\mathrm{a}}$ & Backward & Forward & Total \\
\hline \multicolumn{6}{|l|}{ (a) Other countries } \\
\hline Minimum & 0.0 & 0.0 & 3.3 & 33.3 & 58.2 \\
\hline Maximum & 42.1 & 42.1 & 43.6 & 87.0 & 90.3 \\
\hline Average & 12.2 & 18.6 & 24.0 & 49.0 & 73.0 \\
\hline Weighted-average ${ }^{\#}$ & 22.9 & 24.0 & 24.5 & 46.7 & 71.2 \\
\hline Observations & 43 & 26 & 26 & 26 & 26 \\
\hline \multicolumn{6}{|c|}{ (b) European countries } \\
\hline Minimum & 3.9 & 3.9 & 13.7 & 27.0 & 47.2 \\
\hline Maximum & 42.4 & 42.4 & 48.7 & 69.7 & 86.1 \\
\hline Average & 25.3 & 27.3 & 30.5 & 42.1 & 72.6 \\
\hline Weighted-average $\mathrm{e}^{\#}$ & 34.6 & 35.1 & 25.7 & 46.2 & 71.9 \\
\hline Observations & 33 & 29 & 29 & 29 & 29 \\
\hline \multicolumn{6}{|c|}{$\begin{array}{l}\text { (c) European average minus other country average (as percent of } \\
\text { other country average) }\end{array}$} \\
\hline Weighted-average ${ }^{b}$ & 52 & 46 & 5 & -1 & 1 \\
\hline
\end{tabular}

Backward-, forward-, and total linkages are based on value-added trade flows, while the Grubel-Lloyd index is based on gross trade flows

GL5 5-digit GL index

${ }^{a}$ Countries for which backward, forward, and total linkages are also available

${ }^{\mathrm{b}}$ Based on size of trade flows in 2008 
in characteristics of the supply chain measures for Other Countries (panel a) versus European Countries (panel b) and compares the difference in trade-weighted averages (panel c).

The GL5 column in Table 3 provides the summary statistics of the Grubel-Lloyd index for all 76 countries in the data set (33 European countries and 43 Other countries). It indicates that the range (minimum, maximum, and their difference) is quite similar for Other- and European Countries, but that the weighted average is substantially larger for European countries, namely about 12 percentage points (or about $52 \%$ higher than the Other countries' trade-weighted average). ${ }^{8}$ This motivates why we identify European countries separately. Since we do not have the value-added supply chain measures available for all countries, column GL5* repeats the exercise for the 55 countries for which we do have backward, forward, and total linkages available (29 European countries and 26 Other countries). We arrive at the same conclusion: the average is substantially higher for European countries compared to other countries, namely about 11 percentage points (or about $46 \%$ of the Other countries' trade-weighted average). Again this confirms that European countries stand-out.

The columns backward, forward, and total repeat the exercise for the value-added supply chain measures. There are modest differences in the ranges of the supply chain measures (which is somewhat smaller for European countries in both backward and forward linkages, but somewhat larger for European countries in total linkages). This time, however, there are only small differences in the averages for European versus Other countries, namely of only about one percentage point for backward linkages, forward linkages, and total linkages (which translates to about $5 \%,-1 \%$, and $1 \%$ of the Other countries' trade-weighted averages). The conclusion is therefore simple: the differences between European countries and Other countries regarding the value-added supply chain measures are small, but regarding the Grubel-Lloyd index are substantial.

Figure 6 shows the relationship between the Grubel-Lloyd index and the duration of the decline (in months). The figure depicts a modest positive relationship between the duration of the decline and the Grubel-Lloyd index which is not significant (see Table 4 and the discussion below). This holds for both groups of countries. Among the Other countries group the duration of the decline is, for example, short in China (6 months) with a medium-low Grubel-Lloyd index and long in Canada (22 months) with a high Grubel-Lloyd index, with Japan and the USA in between. Among the European countries the duration of the decline is short in Russia (9 months) with a low Grubel-Lloyd index and long in the UK, Italy, and Germany with a high Grubel-Lloyd index, with a range of small countries in between.

Table 4 provides an overview of the impact of supply chains measured using the Grubel-Lloyd index on nine variables of the Great Recession (note that we included control variables, such as income per capita, volume of trade, and population size; these are not reported and available upon request). The left part of the table focuses

\footnotetext{
${ }^{8}$ Results for GL3 and GL3* are similar to GL5 and GL5* and therefore not reported separately in Table 3.
} 


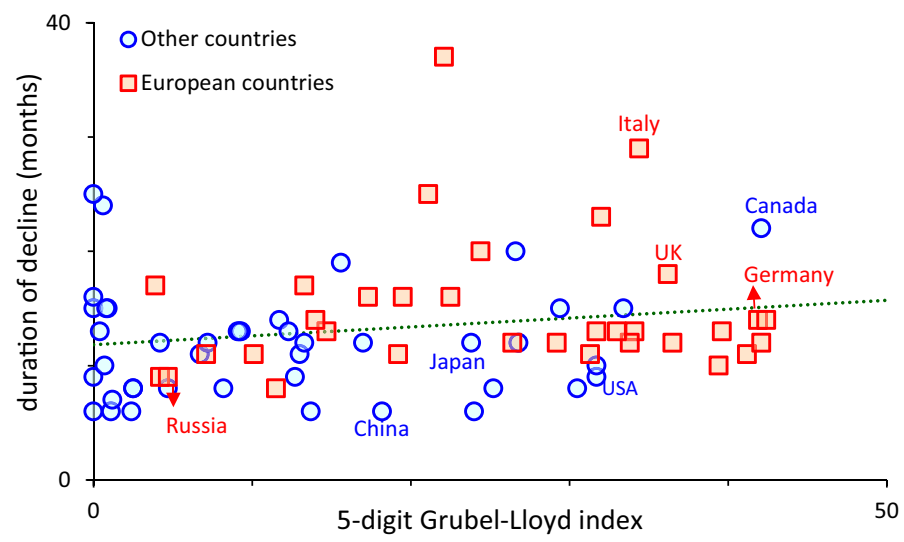

Fig. 6 Grubel-Lloyd index and the duration of the decline in months. Source: Authors's calculations; 76 countries included; dotted line is a regression for all countries

Table 4 Regression overview with intra-industry trade and control variables. Source: Authors's calculations

\begin{tabular}{|c|c|c|c|c|c|c|}
\hline \multirow[t]{2}{*}{ Variable } & \multicolumn{3}{|c|}{ Grubel-Lloyd 5-digit } & \multicolumn{3}{|c|}{ Grubel-Lloyd 3-digit } \\
\hline & $\overline{\text { GL5 }}$ & $\mathrm{P}>|\mathrm{t}|$ & $\mathrm{R}^{2}$ & GL3 & $P>|t|$ & $\mathrm{R}^{2}$ \\
\hline \multicolumn{7}{|c|}{ Timing (year) } \\
\hline Peak & $-0.013 * * *$ & 0.000 & 0.269 & $-0.009 * * *$ & 0.000 & 0.249 \\
\hline Trough & $-0.008 * * *$ & 0.008 & 0.167 & $-0.007 * * *$ & 0.002 & 0.191 \\
\hline Recovery $^{\mathrm{a}}$ & $0.041 * *$ & 0.021 & 0.243 & $0.025 *$ & 0.057 & 0.219 \\
\hline Size $(\%)$ & $0.155 * *$ & 0.029 & 0.084 & $0.134 * * *$ & 0.010 & 0.108 \\
\hline \multicolumn{7}{|c|}{ Duration (months) } \\
\hline Decline & 0.061 & 0.256 & 0.166 & 0.027 & 0.490 & 0.156 \\
\hline Recovery $^{\mathrm{a}}$ & $0.572 * * *$ & 0.007 & 0.258 & $0.365 * *$ & 0.019 & 0.235 \\
\hline Total $^{\mathrm{a}}$ & $0.652 * * *$ & 0.006 & 0.288 & $0.404 * *$ & 0.019 & 0.261 \\
\hline \multicolumn{7}{|c|}{ Speed (\% per month) } \\
\hline Decline & 0.000 & 0.976 & 0.094 & 0.004 & 0.549 & 0.098 \\
\hline Recovery $^{\mathrm{a}}$ & -0.003 & 0.667 & 0.170 & -0.000 & 0.985 & 0.167 \\
\hline
\end{tabular}

Bold emphasis are significant at $10 \%$ or better; number of observations is 76 for peak, trough, decline and size rows and 60 for recovery and total rows; includes controls (reported in "Appendix" Table 8) for $\log$ income per capita, log trade size, and log population size

$p$ values $* 0.1$ significance, $* * 0.05$ significance, $* * * 0.01$ significance ${ }^{a}$ Ignores information on countries which have not yet recovered; see Sect. 6 for survival analysis

on the GL5 index and the right part of the table provides GL3 estimates for comparison. The table shows that a high Grubel-Lloyd index significantly affects the timing of peak (earlier), trough (earlier to a smaller extent), and recovery (later), as well as the size of the decline (bigger), the duration of the recovery, and the total duration (decline + recovery). The duration of the decline only and the speed of decline and recovery are not significantly affected. 


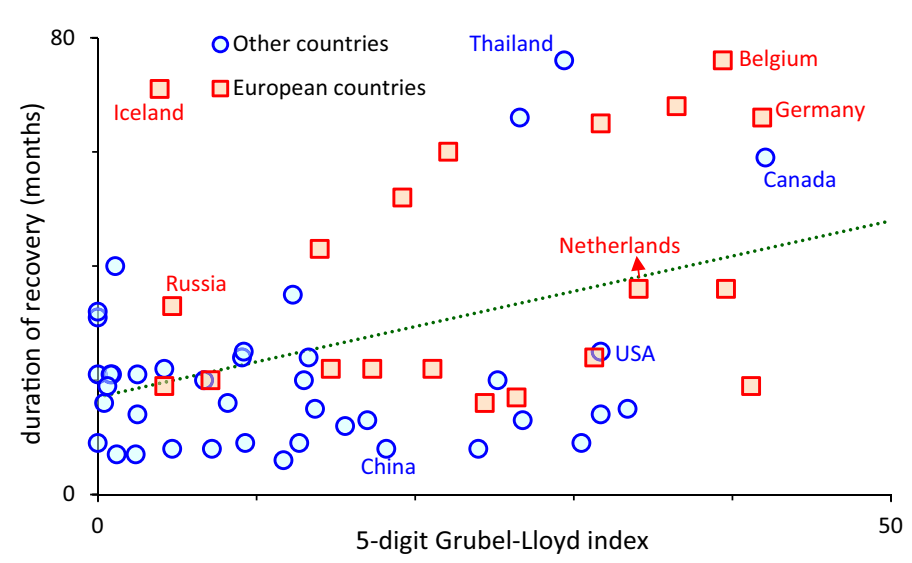

Fig. 7 Grubel-Lloyd index and the duration of the recovery in months. Source: Authors's calculations; 60 countries included; dotted line is a regression for all countries

If we take the 11.1 percentage points higher Grubel-Lloyd index for European countries versus Other countries (see Table 3) for the significant variables of the left part of Table 4 as an indication, this implies that as a result of the more intensive involvement of European countries in supply chains the timing of the trade peak occurred in Europe about 53 days earlier, the trough about 32 days earlier, and the recovery about 166 days later. ${ }^{9}$ As a consequence, the duration of the recovery (for the countries that have recovered) was about 190 days longer, and the total duration about 217 days longer. So, the involvement in global supply chains affects the resilience of countries considerably. ${ }^{10}$

Figure 7 illustrates the longer duration of the recovery for the 60 countries that have recovered. A high Grubel-Lloyd index implies that it takes longer to recover from the Great Recession. Among the Other countries this holds, for example, for Canada and Thailand. Among the European countries it holds, for example, for Belgium and Germany. These findings are consistent with Altomonte et al. (2012) who point out that with longer supply chains a bullwhip effect is likely and also the impact of (export) credit restraints after the crisis might have restricted trade along supply chains.

So what about the countries that have not yet recovered in January 2016 which are excluded from Fig. 7? Part of the reason for their late recovery is related to their involvement in supply chains as measured by the Grubel-Lloyd index. The simple average Grubel-Lloyd index of the countries that have recovered from the Great Recession is $16.2 \%$, which is substantially lower than the $24.0 \%$ average for the countries that have not yet recovered. This discrepancy persists (but becomes somewhat smaller) if we take trade-weighted averages, namely an average of $26.6 \%$ for the recovered countries compared to an average of $31.0 \%$ for the countries that have not yet recovered. We analyse these issues in Sect. 6 .

\footnotetext{
${ }^{9}$ Regarding timing of the peak, for example: -0.013 times 11.1 is -0.14 years or -53 days, and so on.

${ }^{10}$ These effects persist for all variables when a Europe control is added.
} 


\subsection{Value-added measures and the Great Recession}

The Grubel-Lloyd measure allows us to use detailed trade data. A disadvantage is that it is based on gross exports instead of value-added exports. Value-added measures are argued to be more closely related to supply chains, but have to rely on aggregated data. This section provides estimates based on value-added measures. The main relationship between the impact of the Great Recession and the valueadded measures of supply chains is illustrated for backward linkages and the duration of the decline (measured in months) in Fig. 8: there is no relationship. The duration of the decline was short (6 months) in Saudi Arabia with virtually no backward linkages as well as in China and South Korea with substantial backward linkages. Similarly, the duration of the decline was high in Ireland (37 months) with high backward linkages, but also high in Italy and Canada (29 and 22 months) with medium backward linkages. A formal regression shows indeed that there is no relationship between the size of the backward linkages and the duration of the decline in months (see the discussion around Table 5 below for details). The duration of the decline is chosen for illustration purposes as it includes all 55 countries for which we have value-added data, in contrast to the duration of the recovery which includes only 42 countries (see the discussion below and Sect. 6).

Table 5 summarizes the absence of a relationship between value-added supply chain measures and the Great Recession in two parts (note that, as in Sect. 5.1, we include controls such as income per capita, volume of trade, and population size; these results are not in the table but available upon request).

Table 5a analyzes the joint impact of backward and forward linkages on nine different Great Recession variables, namely the timing (in years) of (i) peak, (ii) trough, and (iii) recovery, (iv) the size of the decline, the duration (in months) of (v) the decline, (vi) the recovery, and (vii) in total (sum of decline and recovery), and finally the speed (in percent per month) of (viii) decline and (ix) recovery. Not one of the estimated 18 coefficients is statistically significant. This result is surprising

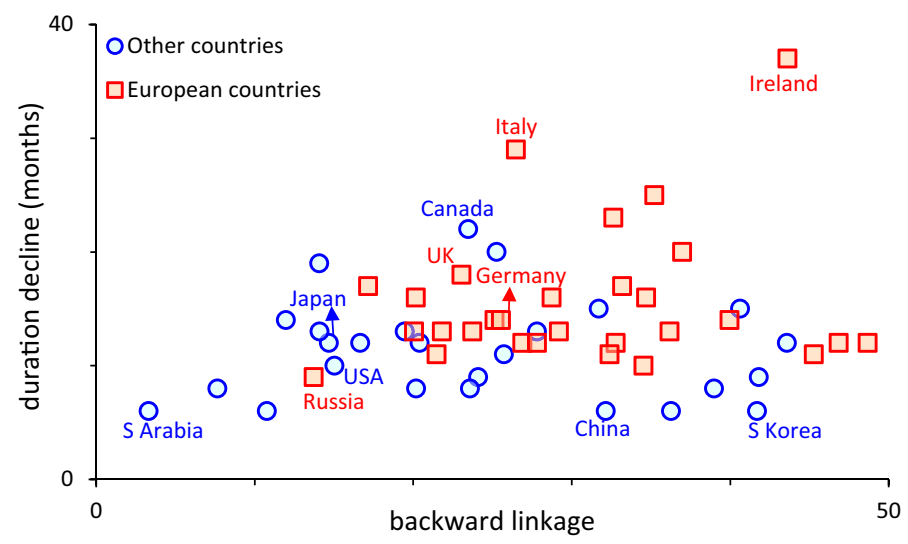

Fig. 8 Backward linkages and the duration of the decline in months. Source: Authors's calculations; 55 countries included 
Table 5 Regression overview with backward and forward linkages as exogenous variable. Source: Authors's calculations

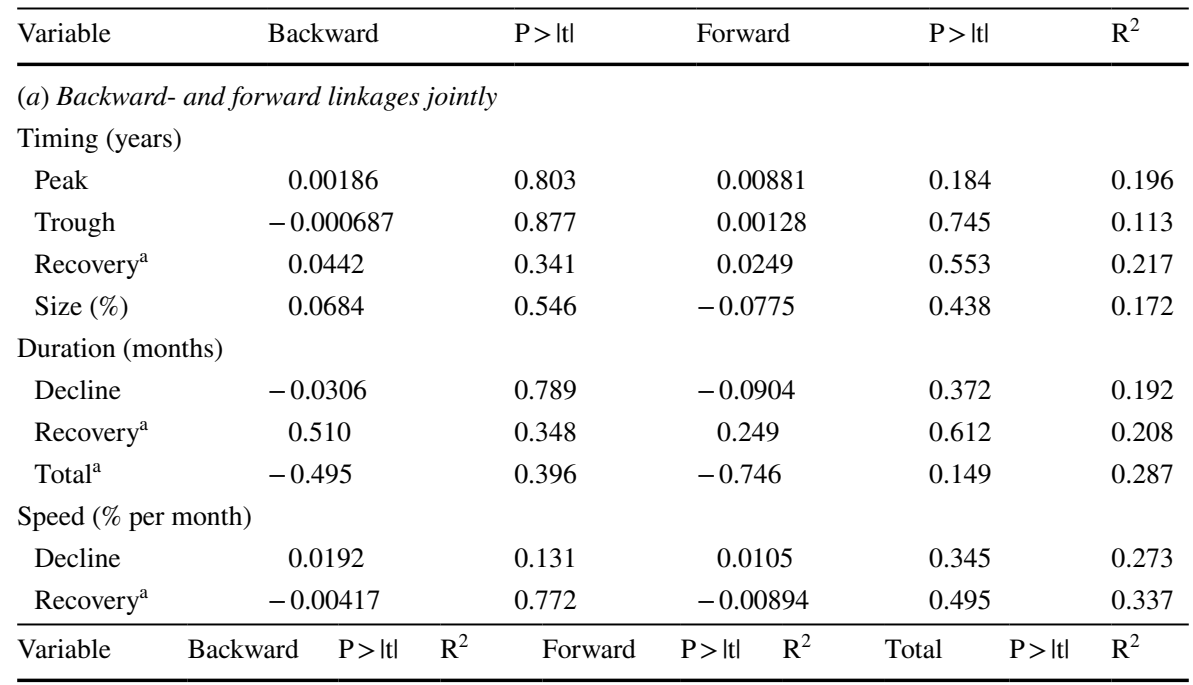

(b) Backward-, forward, and total-linkages separately

Timing (years)

\begin{tabular}{|c|c|c|c|c|c|c|c|c|c|}
\hline Peak & -0.0057 & 0.249 & 0.166 & $0.0076 *$ & 0.080 & 0.195 & 0.0071 & 0.280 & 0.163 \\
\hline Trough & -0.0018 & 0.536 & 0.111 & 0.00173 & 0.495 & 0.113 & 0.0008 & 0.837 & 0.105 \\
\hline Recovery $^{\mathrm{a}}$ & 0.0214 & 0.403 & 0.209 & -0.0084 & 0.719 & 0.196 & 0.0292 & 0.480 & 0.204 \\
\hline Size $(\%)$ & $0.135 *$ & 0.071 & 0.162 & $-0.123 *$ & 0.062 & 0.166 & -0.041 & 0.683 & 0.108 \\
\hline \multicolumn{10}{|c|}{ Duration (months) } \\
\hline Decline & 0.0470 & 0.529 & 0.178 & -0.0700 & 0.286 & 0.191 & -0.076 & 0.445 & 0.181 \\
\hline Recovery $^{\mathrm{a}}$ & 0.283 & 0.346 & 0.202 & -0.136 & 0.620 & 0.188 & 0.307 & 0.527 & 0.191 \\
\hline Total $^{\mathrm{a}}$ & 0.146 & 0.704 & 0.255 & -0.416 & 0.216 & 0.276 & -0.683 & 0.175 & 0.280 \\
\hline \multicolumn{10}{|c|}{ Speed (\% per month) } \\
\hline Decline & 0.0102 & 0.219 & 0.259 & -0.0023 & 0.755 & 0.238 & 0.0127 & 0.247 & 0.257 \\
\hline Recovery $^{\mathrm{a}}$ & 0.00401 & 0.616 & 0.328 & -0.0058 & 0.422 & 0.335 & -0.008 & 0.540 & 0.330 \\
\hline
\end{tabular}

Bold emphasis are significant at $10 \%$ or better; number of observations is 55 for Peak, trough, decline and size rows and 42 for recovery and total rows; includes controls (reported in "Appendix" Table 9) for $\log$ income per capita, log trade size, and log population size

$p$ values $* 0.1$ significance, $* * 0.05$ significance, $* * * 0.01$ significance

${ }^{a}$ Ignores information on countries which have not yet recovered; see Sect. 6 for survival analysis

as supply chain linkages are expected to force countries to move in tandem with respect to recessions, and even to magnify linkages along the supply chain; a possibility explained by Altomonte et al. (2012) in a different setting.

Table $5 \mathrm{~b}$ provides separate estimates of the impact of backward linkages, forward linkages, and total linkages on each of the nine Great Recession variables. Only the timing of the peak is positively affected by forward linkages and the size of the decline is positively affected by backward linkages, which is almost perfectly compensated in the opposite direction by forward linkages, such that there is no effect if 
both are included (see Table 5a). The 24 other estimated coefficients in Table $5 \mathrm{~b}$ are all not statistically significant. We therefore conclude that the value-added supply chain measures have only a limited impact on most economic aspects of the Great Recession.

\section{Survival analysis}

A disadvantage of the recovery and total duration analysis in Sect. 5 is that it excludes the countries which have not yet recovered at the time of the analysis. As this may create a potential bias in our estimates regarding recovery, this section briefly analyzes the duration of the recession (by which we mean the number of months that have passed since a country's trade peak) and the duration of the recovery using survival analysis, which includes information on not-yet-recovered countries. This implies that we use (right) censored data: that is, we observe when a country has recovered, or we observe at the last date in the sample that they are not yet recovered (recovery might or might not occur outside the sample period).

We start with an analysis in Fig. 9 of the trade-weighted Grubel-Lloyd index (GL5) for two groups of countries, namely those that have recovered to the pre-crisis peak level and those that have not-yet-recovered, both after a given number of months. In the first 12 months after the trade peak there are only not-yet-recovered countries, with an average GL5 index of $27.8 \%$. Paraguay recovers after 13 months, followed by Bolivia, China, and South Korea after 14 months. Together these four countries account for $12.3 \%$ of total trade flows. Their average GL5 recovered index is $19.6 \%$, which is substantially lower than the average GL5 index for not-yet-recovered countries after 14 months, which has risen to $28.9 \%$ (since it now excludes Paraguay, Bolivia, China, and South Korea).

Figure 9 illustrates that the discrepancy between recovered and not-yet-recovered countries persists as time goes by. After 50 months 49 countries have recovered,

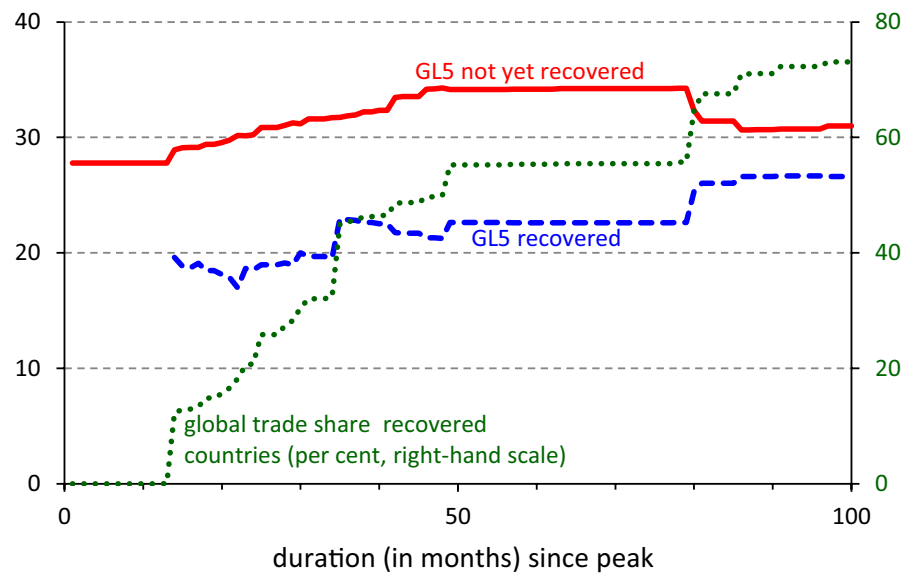

Fig. 9 Duration and Grubel-Lloyd index; recovered and not-yet recovered countries. Source: Authors's calculations; 76 countries included; GL5 = 5-digit trade-weighted Grubel-Lloyd index 
Table 6 Survival analysis; loglogistic distribution. Source: Authors's calculations

\begin{tabular}{lccc}
\hline \multicolumn{4}{c}{ Duration variable } \\
\cline { 2 - 4 } & Decline & Recovery & Total \\
\hline (a) Intra-industry trade & measures $(76$ observations) & \\
Grubel-Lloyd 5-digit & $\mathbf{0 . 0 0 6 3 7 *}$ & $\mathbf{0 . 0 2 0 9 9} * *$ & $\mathbf{0 . 0 1 7 2 6 * * *}$ \\
$p$ value & 0.079 & 0.018 & 0.010 \\
Grubel-Lloyd 3-digit & 0.00392 & $\mathbf{0 . 0 1 5 4 1} * *$ & $\mathbf{0 . 0 1 2 4 8 * *}$ \\
$p$ value & 0.146 & 0.018 & 0.011 \\
(b) Value-added trade & measures $(55$ observations) & \\
Backward linkages & 0.00023 & 0.00237 & 0.00226 \\
$p$ value & 0.962 & 0.847 & 0.809 \\
Forward linkages & -0.00393 & -0.00990 & -0.00868 \\
$p$ value & 0.343 & 0.316 & 0.246 \\
Total linkages & -0.00711 & -0.02357 & -0.01965 \\
$p$ value & 0.215 & 0.162 & 0.123 \\
\hline
\end{tabular}

Since our data exhibit initially rising and then decreasing hazard rates suitable distribution choices are the loglogistic and lognormal distributions. As usual, both lead to similar results

Bold emphasis are significant at $10 \%$ or better; duration in months; regressions are separate per explanatory variable to avoid multicollinearity problems; includes controls (reported in "Appendix" Table 10) for log income per capita, log trade size, and log population size

Backward-, forward-, and total linkages are based on value-added trade flows, while the Grubel-Lloyd index is based on gross trade flows

$p$ values $* 0.1$ significance, $* * 0.05$ significance, $* * * 0.01$ significance

together accounting for $55.2 \%$ of total trade flows. Their average GL5 recovered index is $22.6 \%$, which is substantially lower than the average GL5 not-yet-recovered index after 50 months of $34.1 \%$ for the 27 countries who have not yet recovered. This continues up to 100 months after the trade peak, although the discrepancy gradually diminishes as more and more countries recover. The figure thus illustrates that countries with a high Grubel-Lloyd index take longer to recover from the crisis. Similar graphs for the value-added measures, backward-, forward-, and total-linkages do not show such a difference, see Fig. 11 in the "Appendix".

We can test the observations in Fig. 9 more formally with the use of duration/survival analysis, which focuses on the time it takes for an observation to go from one state to another state. In our case, we can analyse the time it takes to go from peak to trough (column duration decline in Table 6), from trough to recovery (column duration recovery in Table 6), and from peak to recovery (column duration total in Table 6). We are interested whether a strong/weak participation in supply chains affects the probability of moving from one stage to another. In order to assign probabilities to this transition we have to make assumptions regarding the statistical distribution(s) that govern(s) this process. If, for example, $T$ is the time it takes to recover from the trade-trough to the pre-crisis trade-peak and $F(t)=P\{T \leq t\}$ is the 
distribution function with density function $f(t)$, then the survivor function $S(t) \equiv 1-F(t)$ is the probability that it takes longer than $t$ to recover and the hazard function $h(t)$, which is the instantaneous rate of leaving the initial state per unit of time, is defined as: $h(t)=f(t) / S(t)$. Since our data exhibit initially rising and then decreasing hazard rates, suitable distribution choices are the loglogistic and lognormal distributions. As usual, these lead to similar results. In the loglogistic case reported in Table 6 , we have survivor function $S(t)=1 /\left(1+(\lambda t)^{1 / \gamma}\right)$ and density function $f(t)=\left(\lambda^{1 / \gamma} t^{1 / \gamma-1}\right) /\left(\gamma\left(1+(\lambda t)^{1 / \gamma}\right)^{2}\right)$, with $\lambda_{j}=\exp \left(-x_{j} \beta\right)$ and $\gamma$ a parameter to be estimated from the data. ${ }^{11}$

Table 6 provides the survival analysis for the duration variables decline, recovery, and total. Panel $a$ focuses on the two Grubel-Lloyd measures and finds that the Grubel-Lloyd index significantly lenghtens the duration of the recovery and total duration. Only the more detailed GL5 index has an effect on the duration of the decline. Panel $b$ focuses on the three value-added measures and finds that backward-, forward, and total linkages have no effect on the duration of either decline or recovery, nor on total duration. These observations are in line with our findings in Tables 4 and 5. The conclusion of our survival analysis thus confirms the analysis presented throughout this paper.

\section{Conclusion}

Global supply chains link countries to each other. A shock like the Great recession can be expected to transmit itself throughout this chain. We analyse how this linkage affects the extent, the duration, and the time until full recovery of various countries.

The literature on the impact of supply chains on the Great Recession is inconclusive, ranging from studies that argue for a magnification effect of global supply chains on the extent to which the crisis hits a country (like Altomonte et al. 2012) to studies who find only a marginal effect of global supply chains (like Behrens et al. 2013). We address this question for a wide range of countries and therefore allow for heterogeneous country experiences, and whether these can be linked to participation in global supply chains.

We study the impact of the Great Recession by identifying supply chains using the Grubel-Lloyd index and value-added trade measures. The Grubel-Lloyd index allows the use of detailed-gross export_data, while value-added measures can only be applied to a sub-sample of countries using highly aggregated data. Both types of measures highlight different aspects of supply chains; value-added measures stress that part of the production is done elsewhere in the world, whereas the Grubel-Lloyd index emphasizes international intra-industry linkages. The Grubel-Lloyd index has the advantage that countries that are not involved in the fragmentation of production processes, such as Saudi Arabia, are not biasing the indices.

\footnotetext{
11 Estimation uses maximum likelihood. Left-censoring occurs if the starting time is not observed; this is not the case for our observations. Right-censoring occurs if the duration lasts longer than the last time period under investigation; this occurs for 16 countries for the duration of recovery and the total duration.
} 
The main conclusion is straightforward; a strong involvement in global supply chains, as identified by using the Grubel-Lloyd index, raises the size of the decline and slows down the recovery of countries following a recession. Consistent with Altomonte et al. (2012), our results point towards a slow(er) adjustment of production to new expected levels of demand, which could indicate a stronger influence of risk aversion at the macro level or changes in trade conditions, for example, more stringent export credit prerequisites. This, however, is a topic for future research. In contrast, we do not find strong effects for supply chains on the Great Recession when using value-added based measures, like backward-, forward-, and total linkages.

Acknowledgements We would like to thank CPB Netherlands Bureau for Economic Policy Analysis, in particular Jos Ebregt, Paul Veenendaal, Raoul van Maarsseveen, Gerdien Meijerink, and Kasia Grabska, for providing detailed monthly trade data. We are also grateful to Robert Inklaar for some data assistance. We also like to thank the anonymous referees and the editor for detailed comments and suggestions.

Open Access This article is distributed under the terms of the Creative Commons Attribution 4.0 International License (http://creativecommons.org/licenses/by/4.0/), which permits unrestricted use, distribution, and reproduction in any medium, provided you give appropriate credit to the original author(s) and the source, provide a link to the Creative Commons license, and indicate if changes were made.

\section{Appendix}

Table 7 provides an overview of the countries included in our analysis and indicates for which countries we do not have value-added measures available (italicized cells).

Table 7 Overview of 76 countries included in the analysis

\begin{tabular}{llll}
\hline Algeria & Ecuador & Latvia & Singapore \\
Argentina & Estonia & Lithuania & Slovak Rep \\
Australia & Finland & Macedonia & Slovenia \\
Austria & France & Malaysia & South Africa \\
Belarus & Germany & Malta & South Korea \\
Belgium & Guatemala & Mexico & Spain \\
Bolivia & Hong Kong & Morocco & Sweden \\
Brazil & Hungary & Netherlands & Switzerland \\
Bulgaria & Iceland & New Zealand & Taiwan \\
Canada & India & Norway & Tanzania \\
Chile & Indonesia & Oman & Thailand \\
China & Iran & Paraguay & Turkey \\
Colombia & Ireland & Peru & Ukraine \\
Costa Rica & Israel & Philippines & Un. Arab Emirates \\
Croatia & Italy & Poland & United Kingdom \\
Cyprus & Japan & Portugal & United States \\
Czech Rep & Kazakhstan & Romania & Uruguay \\
Denmark & Kenya & Russia & Vietnam \\
Dominican Rep & Kuwait & Saudi Arabia & Zambia \\
\hline
\end{tabular}

No trade in value-added information available for countries with italicized cells 


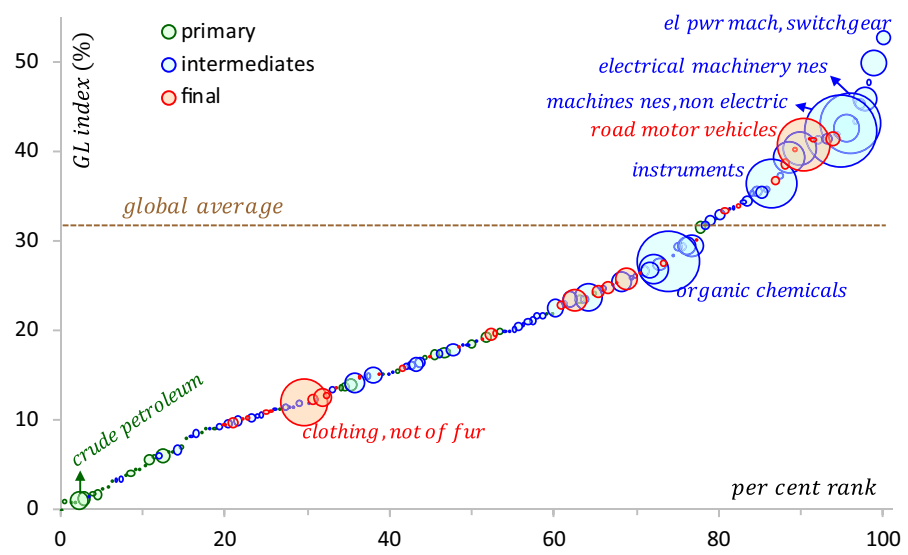

Fig. 10 Global average Grubel-Lloyd index per 3-digit sector at 5-digit level, per cent. Source: Created using Brülhart (2008) data for 2006 at SITC (3rd rev) 5-digit level; bubbles proportional to the size of global trade flows; 177 sectors; nes = not elsewhere specified; el pwr mach is electrical power machines; global trade weighted average is $31.9 \%$; 3 -digit sector BEC product grouping used

Figure 10 illustrates the ranking of the global average Grubel-Lloyd index at the 3-digit level using trade-weighted averages at the 5-digit level. The figure distinguishes the BEC product grouping in primary goods, intermediate goods, and final goods. The global average Grubel-Lloyd index over all sectors is $31.9 \%$. It tends to be low for primary goods (like oil and ores) and high for many of the world's largest trading sectors. This holds, for example for instruments (and apparatus, 7\% of world trade), cars (road motor vehicles, $7.6 \%$ of world trade), machines nes nonelectric (14.6\% of world trade), and electrical machinery nes (10.5\% of world trade). Most of these sectors are prominent in supply chain links.

There are 46 sectors classified as primary goods, accounting for $5 \%$ of global trade flows and with an average GL5 index is of per cent. There are 38 sectors classified as final goods, accounting for $21 \%$ of global trade and with an average GL5 index of $23.5 \%$. There are 93 sectors classified as intermediate goods, accounting for $74 \%$ of global trade and with an average GL5 index of $24.2 \%$. Using this distinction as a basis for identifying supply chains is less useful because intermediate goods account for most trade flows and together with final goods for almost all trade flows, while the GL5 index is quite similar for intermediate and final goods, and the latter category includes prominent supply chain sectors (like cars and aircraft) which one would not like to be excluded from the analysis. We therefore base our analysis on a detailed trade-weighted index at the country level.

Figure 11 shows the duration and value-added linkages for the recovered and notyet recovered countries for the survival analysis of Sect. 6 (compare with Fig. 9). 
(a) backward linkages

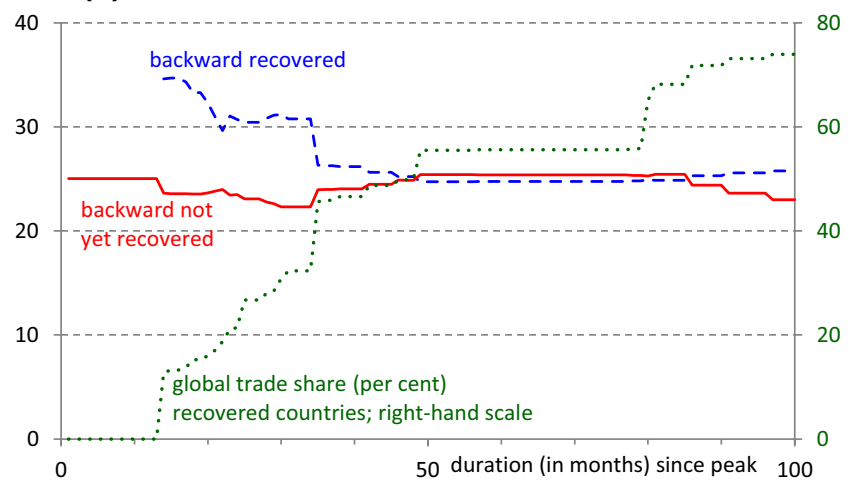

(b) forward linkages

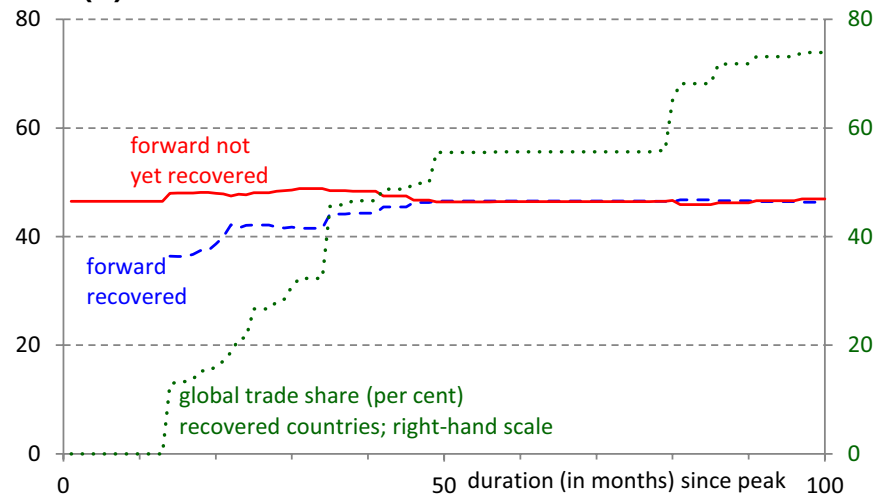

(c) total linkages

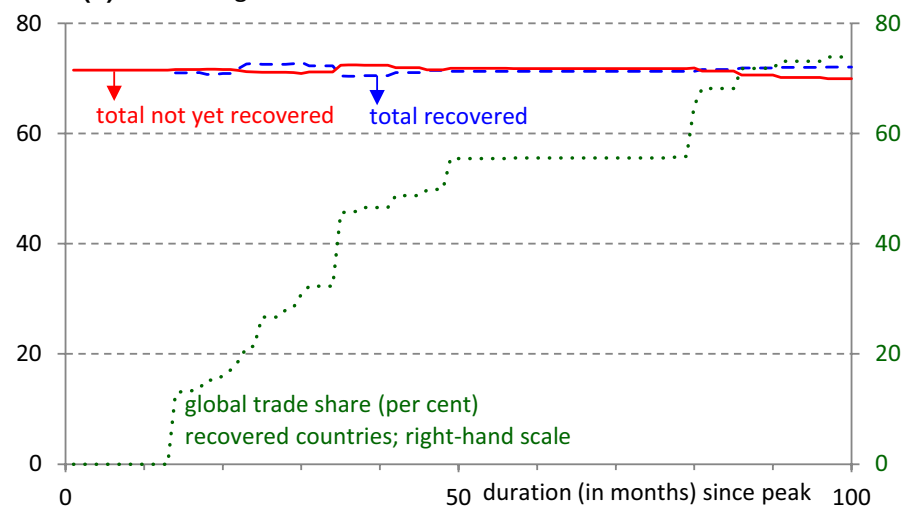

Fig. 11 Duration and value-added linkages; recovered and not-yet recovered countries. Source: Authors's calculations; 55 countries included; linkages are trade-weighted; global trade share of recovered countries is relative to group of 55 countries 


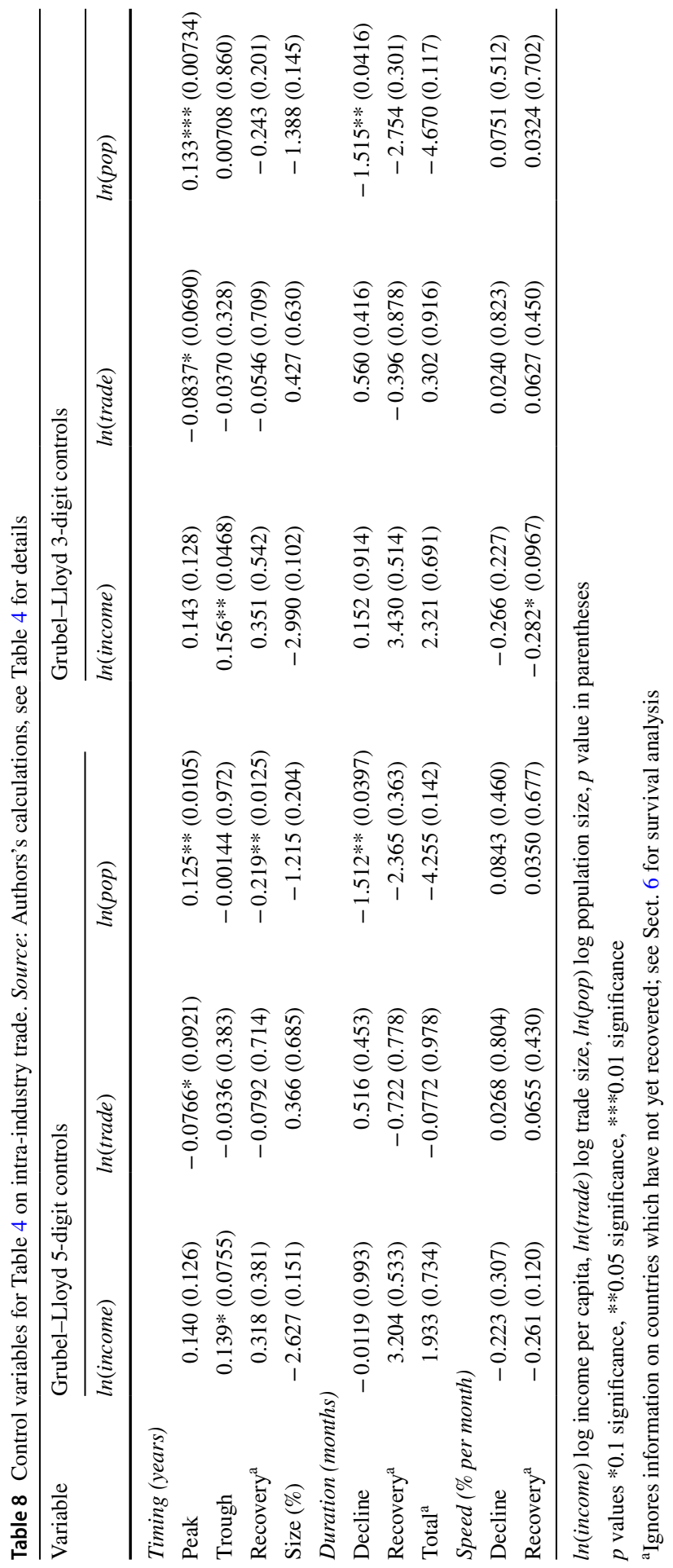


Table 9 Control variables for Table 5 on backward and forward linkages. Source: Authors's calculations, see Table 5 for details

(a) Backward- and forward linkages jointly; controls

\begin{tabular}{|c|c|c|c|}
\hline Variable & $\ln ($ income $)$ & $\ln ($ trade $)$ & $\ln (p o p)$ \\
\hline \multicolumn{4}{|c|}{ Timing (year) } \\
\hline Peak & $-0.0140(0.910)$ & $-0.0545(0.271)$ & $0.0918 *(0.0957)$ \\
\hline Trough & $0.0848(0.251)$ & $-0.0204(0.488)$ & $-0.0114(0.725)$ \\
\hline Recovery $^{\mathrm{a}}$ & $0.931(0.181)$ & $-0.0832(0.765)$ & $-0.134(0.645)$ \\
\hline Size $(\%)$ & $-0.765(0.683)$ & $-0.473(0.528)$ & $-0.288(0.727)$ \\
\hline \multicolumn{4}{|c|}{ Duration (months) } \\
\hline Decline & $1.185(0.532)$ & $0.410(0.589)$ & $-1.238(0.142)$ \\
\hline Recovery $^{\mathrm{a}}$ & $11.02(0.176)$ & $-1.113(0.732)$ & $-1.224(0.719)$ \\
\hline Total $^{\mathrm{a}}$ & $27.66^{* * * *}(0.006)$ & $-2.476(0.519)$ & $0.0768(0.986)$ \\
\hline \multicolumn{4}{|c|}{ Speed ( $\%$ per month) } \\
\hline Decline & $-0.312(0.137)$ & $-0.0475(0.568)$ & $0.140(0.130)$ \\
\hline Recovery $^{\mathrm{a}}$ & $-0.497 * *(0.025)$ & $0.0548(0.529)$ & $0.0413(0.649)$ \\
\hline
\end{tabular}

(b) Backward-, forward, and total-linkages separately; controls

\begin{tabular}{|c|c|c|c|c|c|c|c|c|c|}
\hline \multirow[t]{2}{*}{ Variable } & \multicolumn{3}{|l|}{ Backward } & \multicolumn{3}{|l|}{ Forward } & \multicolumn{3}{|l|}{ Total } \\
\hline & $\ln ($ inc $)$ & $\ln ($ trade $)$ & $\ln (p o p)$ & $\ln ($ inc $)$ & $\ln ($ trade $)$ & $\ln (p o p)$ & $\ln (i n c)$ & $\ln ($ trade $)$ & $\ln (p o p)$ \\
\hline \multicolumn{10}{|c|}{ Timing (years) } \\
\hline Peak & $\begin{array}{l}0.0065 \\
(0.958)\end{array}$ & $\begin{array}{l}-0.0533 \\
(0.286)\end{array}$ & $\begin{array}{l}0.096^{*} \\
(0.084)\end{array}$ & $\begin{array}{l}-0.014 \\
(0.910)\end{array}$ & $\begin{array}{l}-0.054 \\
(0.271)\end{array}$ & $\begin{array}{l}0.090 * \\
(0.096)\end{array}$ & $\begin{array}{l}0.0127 \\
(0.918)\end{array}$ & $\begin{array}{l}-0.057 \\
(0.252)\end{array}$ & $\begin{array}{l}0.110 * * \\
(0.042)\end{array}$ \\
\hline Trough & $\begin{array}{l}0.0877 \\
(0.227)\end{array}$ & $\begin{array}{l}-0.0202 \\
(0.488)\end{array}$ & $\begin{array}{l}-0.0108 \\
(0.736)\end{array}$ & $\begin{array}{l}0.0847 \\
(0.247)\end{array}$ & $\begin{array}{l}-0.0206 \\
(0.479)\end{array}$ & $\begin{array}{l}-0.0108 \\
(0.733)\end{array}$ & $\begin{array}{l}0.0923 \\
(0.204)\end{array}$ & $\begin{array}{l}-0.0212 \\
(0.469)\end{array}$ & $\begin{array}{l}-0.0062 \\
(0.844)\end{array}$ \\
\hline $\begin{array}{c}\text { Recov- } \\
\text { ery }^{\mathrm{a}}\end{array}$ & $\begin{array}{l}1.004 \\
(0.140)\end{array}$ & $\begin{array}{l}-0.0998 \\
(0.716)\end{array}$ & $\begin{array}{l}-0.114 \\
(0.690)\end{array}$ & $\begin{array}{l}0.997 \\
(0.150)\end{array}$ & $\begin{array}{l}-0.107 \\
(0.699)\end{array}$ & $\begin{array}{l}-0.141 \\
(0.626)\end{array}$ & $\begin{array}{l}0.874 \\
(0.203)\end{array}$ & $\begin{array}{l}-0.0825 \\
(0.765)\end{array}$ & $\begin{array}{l}-0.184 \\
(0.514)\end{array}$ \\
\hline Size $(\%)$ & $\begin{array}{l}-0.945 \\
(0.610)\end{array}$ & $\begin{array}{l}-0.484 \\
(0.517)\end{array}$ & $\begin{array}{l}-0.325 \\
(0.692)\end{array}$ & $\begin{array}{l}-0.757 \\
(0.684)\end{array}$ & $\begin{array}{l}-0.453 \\
(0.542)\end{array}$ & $\begin{array}{l}-0.344 \\
(0.673)\end{array}$ & $\begin{array}{l}-1.325 \\
(0.486)\end{array}$ & $\begin{array}{l}-0.415 \\
(0.589)\end{array}$ & $\begin{array}{l}-0.678 \\
(0.411)\end{array}$ \\
\hline \multicolumn{10}{|c|}{ Duration (months) } \\
\hline Decline & $\begin{array}{l}0.975 \\
(0.603)\end{array}$ & $\begin{array}{l}0.397 \\
(0.599)\end{array}$ & $\begin{array}{l}-1.281 \\
(0.127)\end{array}$ & $\begin{array}{l}1.182 \\
(0.529)\end{array}$ & $\begin{array}{l}0.401 \\
(0.593)\end{array}$ & $\begin{array}{l}-1.213 \\
(0.144)\end{array}$ & $\begin{array}{l}0.955 \\
(0.608)\end{array}$ & $\begin{array}{l}0.433 \\
(0.566)\end{array}$ & $\begin{array}{l}-1.398^{*} \\
(0.087)\end{array}$ \\
\hline $\begin{array}{c}\text { Recov- } \\
\text { ery }^{\mathrm{a}}\end{array}$ & $\begin{array}{l}11.75 \\
(0.139)\end{array}$ & $\begin{array}{l}-1.279 \\
(0.690)\end{array}$ & $\begin{array}{l}-1.029 \\
(0.758)\end{array}$ & $\begin{array}{l}11.77 \\
(0.147)\end{array}$ & $\begin{array}{l}-1.387 \\
(0.668)\end{array}$ & $\begin{array}{l}-1.312 \\
(0.699)\end{array}$ & $\begin{array}{l}10.24 \\
(0.204)\end{array}$ & $\begin{array}{c}-1.103 \\
(0.734)\end{array}$ & $\begin{array}{l}-1.899 \\
(0.565)\end{array}$ \\
\hline Total $^{\mathrm{a}}$ & $\begin{array}{l}25.9 * * * \\
(0.009)\end{array}$ & $\begin{array}{l}-2.582 \\
(0.506)\end{array}$ & $\begin{array}{l}-0.281 \\
(0.947)\end{array}$ & $\begin{array}{l}27.6^{* * *} \\
(0.005)\end{array}$ & $\begin{array}{l}-2.617 \\
(0.494)\end{array}$ & $\begin{array}{l}0.478 \\
(0.909)\end{array}$ & $\begin{array}{l}26.7 * * * \\
(0.006)\end{array}$ & $\begin{array}{l}-2.377 \\
(0.533)\end{array}$ & $\begin{array}{l}-0.596 \\
(0.884)\end{array}$ \\
\hline \multicolumn{10}{|c|}{ Speed (\% per month) } \\
\hline Decline & $\begin{array}{l}-0.288 \\
(0.166)\end{array}$ & $\begin{array}{l}-0.0460 \\
(0.580)\end{array}$ & $\begin{array}{l}0.145 \\
(0.116)\end{array}$ & $\begin{array}{l}-0.310 \\
(0.144)\end{array}$ & $\begin{array}{l}-0.0420 \\
(0.618)\end{array}$ & $\begin{array}{l}0.125 \\
(0.180)\end{array}$ & $\begin{array}{l}-0.35^{*} \\
(0.097)\end{array}$ & $\begin{array}{l}-0.0441 \\
(0.596)\end{array}$ & $\begin{array}{l}0.117 \\
(0.191)\end{array}$ \\
\hline $\begin{array}{l}\text { Recov- } \\
\text { ery }^{\text {a }}\end{array}$ & $\begin{array}{l}-0.52^{* *} \\
(0.016)\end{array}$ & $\begin{array}{l}0.0607 \\
(0.480)\end{array}$ & $\begin{array}{l}0.0343 \\
(0.702)\end{array}$ & $\begin{array}{l}-0.50^{* *} \\
(0.021)\end{array}$ & $\begin{array}{l}0.0570 \\
(0.505)\end{array}$ & $\begin{array}{l}0.0420 \\
(0.639)\end{array}$ & $\begin{array}{l}-0.51^{* *} \\
(0.020)\end{array}$ & $\begin{array}{l}0.0549 \\
(0.524)\end{array}$ & $\begin{array}{l}0.0290 \\
(0.740)\end{array}$ \\
\hline
\end{tabular}

$\ln ($ income $) / \ln ($ inc $) \log$ income per capita, $\ln ($ trade $) \log$ trade size, $\ln ($ pop $) \log$ population size, $p$ value in parentheses

$p$ values $* 0.1$ significance, $* * 0.05$ significance, $* * * 0.01$ significance

${ }^{a}$ Ignores information on countries which have not yet recovered; see Sect. 6 for survival analysis 
Table 10 Control variables for Table 6 on survival analysis. Source: Authors's calculations, see Table 6 for details

$$
\text { Duration variable }
$$

Decline Recovery Total

(a) Intra-industry trade measures (76 observations)

Grubel-Lloyd 5-digit

$\begin{array}{lrrr}\ln (\text { income }) & -0.020(0.835) & 0.402 *(0.072) & 0.288 *(0.091) \\ \ln (\text { trade }) & 0.019(0.646) & -0.063(0.566) & -0.042(0.611) \\ \ln (\text { pop }) & -0.102 * *(0.021) & -0.044(0.704) & -0.059(0.497) \\ \text { Grubel-Lloyd 3-digit } & & & \\ \ln (\text { income }) & -0.009(0.923) & 0.393 *(0.082) & 0.284 * * *(0.099) \\ \ln (\text { trade }) & 0.020(0.627) & -0.056(0.612) & -0.036(0.666) \\ \ln (\text { pop }) & -0.102 * *(0.021) & -0.059(0.614) & -0.071(0.420)\end{array}$

(b) Value-added trade measures (55 observations)

Backward linkages

$\begin{array}{lr}\ln (\text { income }) & 0.117(0.278) \\ \ln (\text { trade }) & 0.003(0.947) \\ \ln (\text { pop }) & -0.083^{*}(0.064)\end{array}$

$$
\begin{array}{rr}
0.960 * * *(0.001) & 0.719 * * *(0.001) \\
-0.111(0.336) & -0.077(0.378) \\
0.012(0.925) & -0.015(0.871)
\end{array}
$$

Forward linkages

\begin{tabular}{lrrr}
$\ln ($ income $)$ & $0.127(0.243)$ & $1.011 * * *(0.000)$ & $0.759 * * *(0.000)$ \\
$\ln ($ trade $)$ & $0.007(0.861)$ & $-0.112(0.322)$ & $-0.077(0.367)$ \\
$\ln ($ pop $)$ & $-0.079 *(0.081)$ & $0.034(0.787)$ & $0.003(0.970)$ \\
Total linkages & & & \\
$\ln ($ income $)$ & $0.127(0.233)$ & $1.001 * * *(0.000)$ & $0.753 * * *(0.000)$ \\
$\ln ($ trade $)$ & $0.003(0.948)$ & $-0.117(0.309)$ & $-0.080(0.361)$ \\
$\ln ($ pop $)$ & $-0.083 *(0.059)$ & $0.016(0.896)$ & $-0.014(0.881)$ \\
\hline
\end{tabular}

In(income) log income per capita, $\ln ($ trade) $\log$ trade size, $\ln ($ pop $) \log$ population size, $p$ value in parentheses

$p$ values $* 0.1$ significance, $* * 0.05$ significance, $* * * 0.01$ significance

\section{References}

Altomonte, C., di Mauro, F., Ottaviano, G., Rungi, A., \& Vicard, V. (2012). Global value chains during the great trade collapse: A bullwhip effect? (Working Paper Series, No. 1412). European Central Bank.

Bailey, D., \& Turok, I. (2016). Editorial: Resilience revisited. Regional Studies, 50, 557-560.

Baldwin, R. (2016). The great convergence: Information technology and the new globalization. Cambridge, MA: The Belknap Press of Harvard University.

Behrens, K., Corcos, G., \& Mion, G. (2013). Trade crisis? What trade crisis? Review of Economics and Statistics, 95, 702-709.

Bems, R., Johnson, R. C., \& Yi, K.-M. (2011). Vertical linkages and the collapse of global trade. The American Economic Review, 101, 308-312.

Brakman, S., Garretsen, H., \& van Marrewijk, C. (2015a). Regional resilience across Europe: On urbanisation and the initial impact of the Great Recession. Cambridge Journal of Regions Economies, and Society, 8(2), 225-240. 
Brakman, S., Kohl, T., \& van Marrewijk, C. (2015b). The impact of the transatlantic trade \& investment partnership (TTIP) on low income countries. The Hague: Report for the Dutch Ministery of Foreign Affairs.

Brakman, S., \& van Marrewijk, C. (2017). A closer look at revealed comparative advantage: Gross- versus value-added trade flows. Papers in Regional Science, 96(1), 61-92.

Brülhart, M. (2008). An account of global intra-industry trade (Research Paper Series: Globalisation, productivity and technology. Research Paper 2008/08). University of Nottingham.

Cambridge Journal of Regions, Economy and Society. (2010). The resilient region, Vol. 3.

Ceglowski, J. (2017). Assessing export competitiveness through the lens of value added. The World Economy, 40(2), 275-296.

CPB. (2013). CPB world trade monitor, technical description. CPB Netherlands Bureau for Economic Policy Analysis. http://www.cpb.nl/en/publication/cpb-world-trade-monitor-technical-description.

Egger, P. H., Francois, J., \& Nelson, D. R. (2017). The role of goods-trade networks for services-trade volume. The World Economy, 40(3), 532-543.

Fingleton, B., Garretsen, J. H., \& Martin, R. (2012). Recessionary shocks and regional employment: Evidence on the resilience of UK regions. Journal of Regional Science, 52(1), 109-133.

Irwin, D. (2012). Trade policy disaster. Boston: MIT Press.

Johnson, R. C. (2018). Measuring global supply value chains. Annual Review of Economics, 10, 207-236.

Koopman, R., Powers, W., Wang, Z., Wei, S.-J. (2010). Give credit where credit is due: Tracing value added in global supply chains. NBER Working Paper, No. 16426, Cambridge Mass.

Martin, R., \& Sunley, P. (2015). On the notion of regional economic resilience: Conceptualization and explanation. Journal of Economic Geography, 15, 1-42.

Martin, R., Sunley, P., Gardiner, B., \& Tyler, P. (2016). How regions react to recessions: Resilience and the role of economic structure. Regional Studies, 50, 561-585.

Raumforschung und Raumordnung. (2014). Special issue on regional economic resilience: Policy experiences and issues in Europe, Vol. 72(2).

Regional Studies. (2016). Special theme issue: resilience revisited, No. 4.

Salvatore, D. (2017). Europe's growth crisis: How and when will it end? The World Economy, 40(5), 836-848.

van Marrewijk, C. (2017). International trade. Oxford: Oxford University Press.

Wagner, J., \& Gelübcke, J. P. W. (2014). Risk or resilience? The role of trade integration and foreign ownership for the survival of German enterprises during the Crisis 2008-2010. Jahrbücher für Nationalökonomie und Statistik, 234(6), 757-774.

World Bank. (2009). World development report 2009: Reshaping economic geography. Washington, DC: The World Bank.

World Trade Organization. (2009). World trade report, Geneva.

Publisher's Note Springer Nature remains neutral with regard to jurisdictional claims in published maps and institutional affiliations. 